\title{
Non-invasive genetic sampling for molecular sexing and microsatellite genotyping of hyacinth macaw (Anodorhynchus hyacinthinus)
}

\author{
Flavia T. Presti ${ }^{1}$, Janaína Meyer ${ }^{1}$, Paulo T.Z. Antas $^{2}$, Neiva M.R. Guedes ${ }^{3}$ and Cristina Y. Miyaki ${ }^{1}$ \\ ${ }^{1}$ Departamento de Genética e Biologia Evolutiva, Instituto de Biociências, Universidade de São Paulo, \\ São Paulo, SP, Brazil. \\ ${ }^{2}$ PTZA Consultoria em Meio Ambiente, Brasília, DF, Brazil. \\ ${ }^{3}$ Anhanguera Educacional \& Instituto Arara Azul, Campo Grande, MS, Brazil.
}

\begin{abstract}
Molted feather sampling is a useful tool for genetic analyses of endangered species, but it is often very laborious due to the low quality and quantity of the DNA obtained. In the present study we show the parts of feathers that resulted in better yield of DNA. In descending order these were: blood clot outside the umbilicus, umbilicus (without blood clot), tip, inner membrane, and small calamus. Compared to DNA extracted from blood samples, DNA extracted from feathers produced microsatellite alleles of poorer quality and had to be processed immediately after extraction. As expected due to the level of DNA degradation, molecular sexing protocols that result in shorter PCR products were more efficient.
\end{abstract}

Keywords: molted feathers, blood sample, DNA, PCR product, parrot.

Received: February 28, 2012; Accepted: October 9, 2012.

Molecular studies require the collection of biological samples. In nature, some organisms cannot be safely captured, or are rarely seen. In such cases, non-invasive samples, such as molted feathers, egg shells, feces or hair, may be the only source of genetic material (Morin et al., 2001). However, these samples usually yield a small amount of low quality DNA that can even be contaminated with PCR inhibitors. Nevertheless, molted feathers can be good sources of DNA (Russello and Amato, 2001; Horváth et al., 2005; Seki, 2006; Miño and Del Lama, 2009; Rudnick et al., 2009). A study by Speller et al, (2011) using a few feather barbs could sequence and identify eight species of birds after applying two methods of DNA extraction. Such feathers probably have a blood clot that is the remnant of the axial artery which is reabsorbed during feather development and known as the umbilicus blood clot (Proctor and Lynch, 1993). This clot was a good source of DNA from small feathers of the Spanish imperial eagle, Aquila adalberti (Horváth et al., 2005).

DNA extracted in a good quality may be used, for example, to determine the genetic similarity among pairs of individuals, or in paternity tests based on microsatellite analyses. It can also be used to determine the sex ratio based on the amplification of a sex linked gene (e.g. CHD-

Send correspondence to Flavia T. Presti. Departamento de Genética e Biologia Evolutiva, Instituto de Biociências, Universidade de São Paulo, Rua do Matão 277, 05508-090 São Paulo, SP, Brazil. E-mail: flapresti@ hotmail.com.
1; Griffiths et al., 1998; Bantock et al., 2008). Such data was also produced for chicks of hyacinth macaw, Anodorhynchus hyacinthinus (Faria and Miyaki, 2006; Faria et al., 2007), which is a large and vulnerable parrot species whose adults cannot be easily caught in the wild. Notwithstanding, it would be important to have genetic and sex data for adults, and especially so, it would be important to access the DNA of social parents to test if they are the actual biological parents. In this case, molted feathers could be a good source of DNA from adult individuals. In the present study we evaluated the use of molted feathers from hyacinth macaws as DNA sources for genetic studies. Our objectives were to: 1) determine which part of the molted feather is the best DNA source, 2) compare the efficiency of microsatellite amplification of DNA from feather and blood, and 3) sex DNA from molted feathers.

We initially used 13 molted feathers of hyacinth macaws to test which region of the feather was the best source of DNA. These feathers (maximally 1 day on the ground) were collected under three suspended aviaries in a captive breeding facility. Two of these aviaries had one couple each, and the last aviary had a couple and a female (Table 1). The sex of the individuals was informed by Lymington Foundation (where samples were collected) and checked by molecular sexing protocol with the primers P2 and $\mathrm{P} 8$ described below. From 13 feather used, six were small $(<2.0 \mathrm{~cm})$. As it was not possible to separate them into parts, the entire calamus of these feathers was used to 


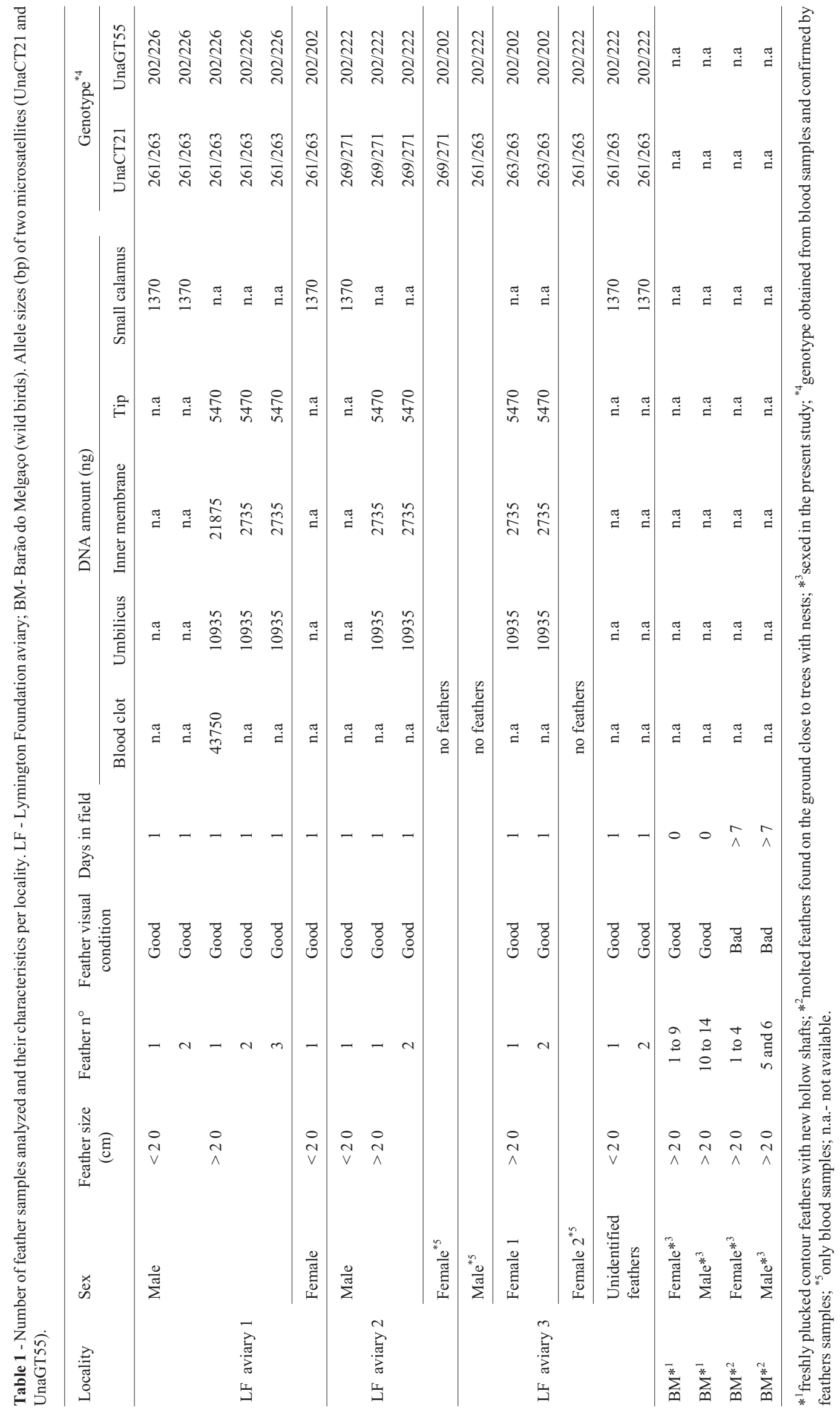


extract DNA. Blood samples of all individuals were also collected to compare microsatellite quality to that from the feathers of these birds. Feathers were stored in paper envelopes and blood samples were stored in absolute ethanol. The samples were kept at $-20{ }^{\circ} \mathrm{C}$ at the Laboratório de Genética e Evolução Molecular de Aves (Instituto de Biociências, Universidade de São Paulo).

To test if it was possible to sex feathers collected in the wild, we used feathers collected in Barão do Melgaço, MT, consisting of 14 freshly plucked contour feathers with new hollow shafts and 11 molted feathers found on the ground close to trees with nests (Table 1). The general visual condition of the feathers found on the ground was classified as bad.

To test if different regions of the calamus yield different quantities and/or quality of DNA, seven calami bigger than $2 \mathrm{~cm}$ in length had three or four regions investigated (Figure 1): 1) the tip of approximately $0.3 \mathrm{~mm}$ in length, 2) the inner membrane, 3 ) a clot of blood found in the inner membrane but outside the umbilicus region, and 4) the umbilicus region. The external portion of the feather was not used for DNA extraction. Additionally, six calami shorter than $2 \mathrm{~cm}$ in length were completely chopped into tiny pieces. To avoid contamination with DNA from other birds, the extraction and PCR was performed in another laboratory (Laboratório de Ictiogenética of the University of São Paulo). The feather was washed with MiliQ water and cut into pieces with a sterile scalpel blade.

DNA from all molted feathers was extracted with DNeasy Tissue Kit (QIAGEN), with modifications described as follows. During the initial digestione $30 \mu \mathrm{L}$ of dichlorodiphenyltrichloroethane (DDT; $0.1 \mathrm{~g} / \mathrm{mL}$ ) were added and the reaction mix incubated at $56^{\circ} \mathrm{C}$ until the tissue was completely digested (approximately $6 \mathrm{~h}$ ). DNA was eluted with $50 \mu \mathrm{L}$ of Buffer AE (instead of $200 \mu \mathrm{L}$ ). All extractions were accompanied by a negative control used to detect any possible contamination. DNA from blood and plucked contour feathers with new hollow shafts $(<2 \mathrm{~cm}$ and chopped) was extracted individually, using a standard protocol of digestion with proteinase $\mathrm{K}$ followed by purification with phenol: chloroform: isoamyl alcohol

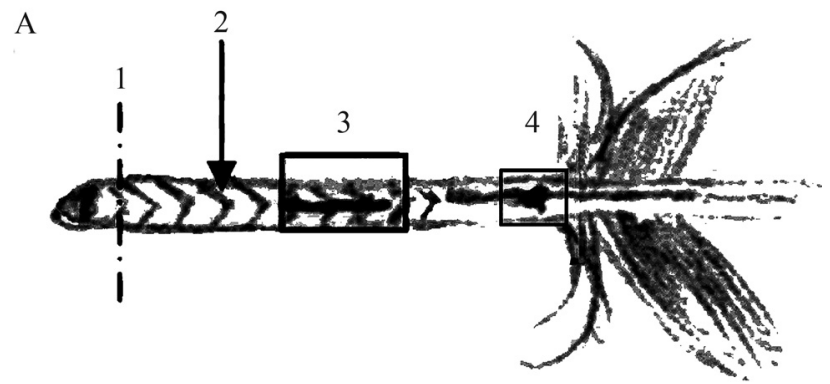

Figure 1 - General view of a typical flight feather: The four different areas of the calamus that were tested are shown: (1) tip, (2) inner membrane, (3) blood clot outside the umbilicus, and (4) umbilicus clot. Modified from Horváth et al. (2005).
(25: 24: 1) described by Bruford et al. (1992). This protocol is cheaper than the extraction using the kit. However, initial testing showed that this protocol does not work for molted feathers, and therefore different protocols were used.

Approximately $1 \mu \mathrm{L}$ of each extraction product was separated by electrophoresis in $1 \%$ agarose gels along with DNA concentration standards ( $\lambda$ DNA: $62.5 \mathrm{ng} / \mu \mathrm{L}$, $125 \mathrm{ng} / \mu \mathrm{L}$ and $250 \mathrm{ng} / \mu \mathrm{L}$ ) to quantify the amount of extracted DNA.

Two pairs of heterologous microsatellite primers developed for Ara ararauna (Caparroz et al., 2003) and previously tested in hyacinth macaws (Presti et al., 2011) were used: UnaCT21 and UnaGT55 (Caparroz et al., 2003). Amplification reactions were performed in a final volume of $12 \mu \mathrm{L}$, with $7.2 \mu \mathrm{L}$ of MilliQ water, $1.2 \mu \mathrm{L}$ of buffer (10X), $1.0 \mu \mathrm{L}$ of dNTPs $(2 \mathrm{mM}), 0.4 \mu \mathrm{L}$ of $\mathrm{MgCl}_{2}(25 \mathrm{mM}), 0.3 \mu \mathrm{L}$ of reverse primer $(10 \mu \mathrm{M}), 0.2 \mu \mathrm{L}$ of M13 primer $(10 \mu \mathrm{M})$ labeled with fluorescence (HEX and TET, Applied Biosystems), $0.1 \mu \mathrm{L}$ of forward primer with a $5^{\prime} \mathrm{M} 13$ tail $(10 \mu \mathrm{M}), 0.1 \mu \mathrm{L}$ of Taq polymerase $(5 \mathrm{U} / \mu \mathrm{L}$, GE Healthcare), and $1.5 \mu \mathrm{L}$ of DNA (20-50 ng). PCR conditions were: denaturation at $95^{\circ} \mathrm{C}$ for $10 \mathrm{~min}, 35$ cycles of denaturation at $95{ }^{\circ} \mathrm{C}$ for $1 \mathrm{~min}$, annealing at $50^{\circ} \mathrm{C}-60^{\circ} \mathrm{C}$ for $40 \mathrm{~s}$, and extension at $72{ }^{\circ} \mathrm{C}$ for $40 \mathrm{~s}$, and finally, an extension step at $72{ }^{\circ} \mathrm{C}$ for $10 \mathrm{~min}$. Quality and quantity of the amplification products was checked by electrophoresis of $1.5 \mu \mathrm{L}$ of each product in $1.5 \%$ agarose gels.

$0.6 \mu \mathrm{L}$ of the molecular marker Genescan-500 TAMRA ( 2 pmol; Applied Biosystems), $2.0 \mu \mathrm{L}$ of formamide, and $0.4 \mu \mathrm{L}$ of blue dextran $(50 \mathrm{mg} / \mathrm{mL})$ were mixed with $1.5 \mu \mathrm{L}$ of each amplified sample, and $4.0 \mu \mathrm{L}$ of this mixture was analyzed in an ABI 377 automated sequencer (Applied Biosystems). The identification of allele sizes was performed using the program Genotyper 2.1 (Perkin Elmer). All amplification reactions were repeated two to four times to confirm the allele identification of 13 molted feathers using the DNA derived from all feathers portions or units extractions and seven blood samples.

We initially tested the primers $\mathrm{P} 2$ and $\mathrm{P} 8$ (Griffiths et al., 1998) in a final reaction volume of $10 \mu \mathrm{L}$, with $4.7 \mu \mathrm{L}$ of MilliQ water, $1.0 \mu \mathrm{L}$ of buffer (10X), $1.0 \mu \mathrm{L}$ of dNTPs $(2 \mathrm{mM}), 0.2 \mu \mathrm{L}$ of $\mathrm{MgCl}_{2}(25 \mathrm{mM}), 0.1 \mu \mathrm{L}$ of Taq polymerase ( $5 \mathrm{U} / \mu \mathrm{L}, \mathrm{GE}$ Healthcare), $1 \mu \mathrm{L}$ of each primer, and $1 \mu \mathrm{L}$ of DNA (20-50 ng). Reaction conditions were: denaturation at $95^{\circ} \mathrm{C}$ for $5 \mathrm{~min}, 40$ cycles of denaturation at $95^{\circ} \mathrm{C}$ for $1 \mathrm{~min}$, annealing at $43{ }^{\circ} \mathrm{C}$ for $30 \mathrm{~s}$, extension at $72{ }^{\circ} \mathrm{C}$ for $30 \mathrm{~s}$, and final extension step at $72{ }^{\circ} \mathrm{C}$ for $7 \mathrm{~min}$. Samples that could not be sexed with this set of primers were amplified with the primers M5 (Bantock et al., 2008) and P8, that result in a shorter product. Reactions were performed under the same conditions but with an annealing temperature of $54{ }^{\circ} \mathrm{C}$. The products were separated in $3 \%$ agarose gels, and all reactions were performed using a positive control (sam- 
ple of a previously sexed female hyacinth macaw) and ultrapure water as a negative control.

Horváth et al. (2005) reported that they found a blood clot at the umbilicus in small feathers of Aquila adalberti. We did not find any blood clot in the umbilicus region, but in one of the feathers a blood clot was observed outside the umbilicus region (Figure 1). It is possible that the presence of this clot is related to the feather's age, i.e. the earlier it falls, the less the clot is reabsorbed and, thus, can be found in molted feathers.

Our results showed that the regions of the calamus that resulted in better yield of DNA, in decreasing order, were: blood clot outside the umbilicus, umbilicus (without blood clot), tip, inner membrane, and small calamus (Table 1, Figure 1). Even if a blood clot in the umbilicus region was not found, as in the results reported by Horváth et al. (2005), more DNA was obtained from the umbilicus than from the tip of long feathers $(>2.0 \mathrm{~cm})$. Our results showed that small feathers produce smaller amounts of DNA than all parts from large feathers taken together. Blood samples yielded approximately 15 times more DNA than the best part of the feather analyzed. The same result was observed in other macaw species (Ara ararauna, Ara chloropterus, and Ara macao) with higher success rates of microsatellite amplification with samples extracted from large feathers than from small ones (Gebhardt et al., 2009).

The two microsatellite primer pairs generated analyzable products from all seven blood samples and from 13 feathers obtained from the captive facility. However, samples with less DNA yielded poorer quality alleles, with smaller electrophoretic peaks, some alleles having unexpected sizes (possibly as a result of DNA degradation), some alleles failing to amplify (allele dropout), and some samples presenting unspecific bands (i.e. one individual with three alleles). Taberlet et al. (1996) also observed genotyping problems when the amount of DNA was limited, and recommended that at least two amplification replicates be performed for heterozygous loci and seven replicates to confirm homozygosity. In our study we did two replicates for heterozygous loci and four replicates to confirm homozygous loci in the blood samples. To obtain the same efficiency with the feather samples, we genotyped four replicates for heterozygous and six to eight to confirm homozygosity. We also observed that results were better when amplifications had been performed immediately after DNA extraction. PCR replicates performed at the same time and immediately after extraction gave less nonspecific and clearer peaks, apparently by avoiding DNA degradation. Previous tests had shown that this strategy is successful, as non-degraded DNA becomes degraded over time. Difficulties with the use of feathers were also noted in a study comparing different sampling methods for microsatellite genotyping from Red Junglefowl (Galliformes). Mukesh et al. (2011) found a DNA yield gradient in blood, plucked feathers and shed feathers in the ratio 22:2:1, re- spectively. DNA extracts from feathers were amplified for four microsatellite loci. When genotyping the DNA extracts of shed $(n=12)$ and plucked $(n=6)$ feathers, three samples $(17 \%)$ were successfully genotyped for all four microsatellite loci, four samples $(22 \%)$ for three and two loci each, and seven samples (39\%) for one locus (Mukesh et al., 2011).

Despite the fact that only two microsatellite loci were analyzed herein, each individual had a unique genotype profile based on the analysis of their blood samples (Table 1). The only exceptions were two birds (one male and one female) from aviary 3 , who shared the same profile. Thus, it was possible to assign 11 of the 13 feathers to a given individual (Table 1). For one of the four feathers from aviary 2, the alleles of loci UnaGT55 were not analyzable, so it was only based on blood samples. One of the three feathers from aviary 3 yielded a genotype profile shared by two birds, and it could not be assigned to any of them (Table 1). As one macaw was a male and the other a female, we tried to sex this feather, but the result was not conclusive.

It was possible to sex 12 of the 14 contour feathers from the BM samples (86\%) with primers P2 and P8 (Griffiths et al., 1998), while none of the 11 molted feathers collected near the nests yielded any product. This result was expected because the general aspect of the freshly plucked contour feathers was better than that of the feathers found on the ground, and general feather condition can be used as a predictor of DNA quality (Gebhardt et al., 2009). The samples that failed to amplify were further tested with primers M5 (Bantock et al., 2008) and P8 that produce shorter bands ( 250 to $300 \mathrm{bp}$ ). After two attempts, because some samples were unreliable and were therefore repeated, it was possible to identify the gender of the last two contour feathers and six of $11(56 \%)$ unsexed feathers found on the ground (Table 1). This was expected, as the primer set M5 and P8 amplifies shorter products that are more easily amplified, and the DNA samples used in the present study were degraded. It would thus be desirable to test other DNA extraction protocols to reduce degradation effects. Our study is in agreement with Harvey et al. (2006) that provided evidence that feathers can yield sufficient DNA for molecular sexing. This authors compared the efficiency of sex determination based on feather vs. blood samples.

McDonald and Griffith (2012) emphasize that currently there is still a lack of data that test the impacts of feather sampling, either from feather plucking or clipping, which makes it very difficult to judge the long-term impacts of these techniques. They encourage researchers to publish data on any potential impacts of feather sampling. Even though laboratory processing is more laborious and expensive when using feathers found in the wild, the present study and others show that such feathers, when collected as freshly as possible, can be valuable DNA sources (Griffiths and Tiwari, 1995; Russello and Amato, 2001; Gebhardt et al., 2009; Miño and Del Lama, 2009; Katzner 
et al., 2012). It is especially useful in studies of animals that are not easy to be captured. These samples can be used to amplify microsatellites and sex-linked markers that are used in a number of studies, such as population structure, paternity, sex ratio, and others.

\section{Acknowledgments}

We thank the Fundação Lymington for blood and feather samples from captive birds. This study was supported by Fundação de Amparo à Pesquisa do Estado de São Paulo (FAPESP), Coordenação de Aperfeiçoamento de Pessoal de Nível Superior (CAPES), and Conselho Nacional de Desenvolvimento Científico e Tecnológico (CNPq).

\section{References}

Bantock TM, Prys-Jones RTP and Lee, PLM (2008) New and improved molecular sexing for museum bird specimens. Mol Ecol Notes 8:519-528.

Bruford MW, Hanotte O, Brookfield JFY and Burke T (1992) Single locus and multilocus DNA fingerprinting. In: Hoelzel CAR (ed) Molecular Genetic Analyses of Populations: A Pratical Approach. Oxford University Press, New York, pp 225-269.

Caparroz R, Miyaki CY and Baker AJ (2003) Characterization of microsatellite loci in the Blue-and-gold Macaw, Ara ararauna (Psittaciformes, Aves). Mol Ecol Notes 3:441443.

Faria PJ and Miyaki CY (2006) Molecular markers for population genetic analyses in the family Psittacidae (Psittaciformes, Aves). Genet Mol Biol 29:231-240.

Faria PJ, Guedes NMR, Yamashita C, Martuscelli P and Miyaki CY (2007) Genetic variation and population structure of the endangered Hyacinth Macaw (Anodorhynchus hyacinthinus): Implications for conservation. Biodivers Conserv 17:765-779.

Gebhardt KJ, Brightsmith D, Powell G and Waits LP (2009) Molted feathers from clay licks in Peru provide DNA for three large macaws (Ara ararauna, Ara chloropterus and Ara macao). J Field Ornithol 80:183-192.

Griffiths R and Tiwari B (1995) Sex of the last wild Spix's macaw. Nature 375:454.

Griffiths R, Double M, Orr KCY and Dawson RJG (1998) A DNA test to sex most birds. Mol Ecol 7:1071-1075.

Harvey MG, Bonter DN, Stenzler LM and Lovette IJ (2006) A comparison of plucked feathers $v s$. blood samples as DNA sources for molecular sexing. J Field Ornithol 77:136-140.

Horváth MB, Martínez-Cruz B, Negro JJ, Kalmár L and Godoy JA (2005) An overlooked DNA source for non-invasive genetic analysis in birds. J Avian Biol 36:84-88.
Katzner TE, Wheeler M, Negro JJ, Kapetanakos Y, DeWoody JA, Horvath M and Lovette I (2012) To pluck or not to pluck: Scientific methodologies should be carefully chosen, not 'one size fits all'. J Avian Biol 43:15-17.

McDonald PG and Griffith SC (2012) Feather sampling provides an unreliable source of DNA that may well have significant long-term impacts: A reply to Katzner et al. J Avian Biol 43:001-003.

Miño CI and Del Lama SN (2009) Molted feather as a souce of DNA for genetic studies in waterbird population. Waterbirds 32:322-329.

Morin PA, Chambers KE, Boesch C and Vigilant L (2001) Quantitative polymerase chain reaction analysis of DNA from noninvasive samples for accurate microsatellite genotyping of wild chimpanzees (Pan troglodytes verus). Mol Ecol 10:1835-1844.

Mukesh MF, Mandhan RP and Sathyakumar S (2011) Comparison of different parameters of invasive and non invasive sampling methods for microsatellite genotyping: A case study from Red Junglefowl and its application for other Galliformes. J Res Biol 1:38-43.

Presti FT, Oliveira-Marques AR, Caparroz R, Biondo C and Miyaki CY (2011) Comparative analysis of microsatellite variability in five macaw species (Psittaciformes, Psittacidae): Application for conservation. Genet Mol Biol 34:348-352.

Proctor NS and Lynch PJ (1993) Manual of Ornithology. Avian structure and function. Yale University Press, New Haven, $352 \mathrm{pp}$.

Rudnick JA, Katzer TE and DeWoody JA (2009) Genetic analyses of noninvasively collected feathers can provide new insights into avian demography and behavior. In: Aronoff JB (ed) Handbook of Nature Conservation. Nova Science Publishers, New York, pp 181-197.

Russello MA and Amato G (2001) Application of a non-invasive, PCR-based test for sex identification in an endangered parrot, Amazona guildingii. ZooBiology 20:41-45.

Seki S (2006) Application of molted feathers as noninvasive samples to studies on the genetic structure of pigeons (Aves, Columbidae). J Forest Res 11:125-129.

Speller CF, Nicholas GP and Yang DY (2011) Feather barbs as a good source of mtDNA for birds species identification in forensic wildlife investigation. Invest Genet 2:16.

Taberlet P, Griffin S, Goossens B, Questiau S, Manceau V, Escaravage N, Waits LP and Bouvet J (1996) Reliable genotyping of samples with very low DNA quantities using PCR. Nucleic Acids Res 24:3189-3194.

\section{Associate Editor: Antonio Matteo Solé-Cava}

License information: This is an open-access article distributed under the terms of the Creative Commons Attribution License, which permits unrestricted use, distribution, and reproduction in any medium, provided the original work is properly cited. 